\title{
めまい診療と迷路病態
}

一特にメニエール病のめまい発作中に於ける迷路病態の変化一

$$
\text { 朴 沢 二 郎 }
$$

\section{Labyrinthine Pathophysiology for Treatment of Vertigo}

\author{
Jiro Hozawa \\ (Hirosaki University School of Medicine)
}

The labyrinthine pathophysiology during the occurrence of aural vertigo was investigated by clinical observations and animal experiments.

As a rule, irritative or paralytic nystagmus can be frequently observed during the vertiginous attack. In order to know the mechanism of nystagmus, a histochemical study of the vestibular sensory cells and autoradiographic study of the vestibular nuclei were performed for the model animals of the Meniere's attack. From the results, it was proved that the excitement of the affected side labyrinth and ipsilateral vestibular nucleus provoked irritative nystagmus. On the other hand, paralytic nystagmus was provoked by the paralysis of the affected side labyrinth and the excitement of the contralateral vestibular nucleus.

Key words: mechanism of the Meniere's attack, nystagmus, electrocochleogram, histochemistry of the inner ear sensory cells, autoradiography of the vestibular and cochlear nuclei

はじめに

耳性めまいの診療に際し, 迷路の病態を十分 に把握する事の必要性は申すまでもない，特に めまい発作中に迷路病態がどの様に変化するか を理解する事は適格な治療を行ら上で極めて重 要である.

さて，末梢および中枢を含む左右前庭系の何 処かに急激な破綻を生じた場合に, 発作的にめ まいの起こる事はよく知られている.しかし， めまい発作中に迷路の病態がどの様に变化する か?に関しては，未だ具体的に明らかにされて いない.

そこで，本章では耳性めまいの発作中に迷路
病態がどの様に変化するかについて，これまで 筆者の教室が行って来た研究成績を述べ諸家の 御批判を得たいと思う（尚, 論旨の基礎となる 具体的データーについては本文の末尾文献に記 した原著を参照されたい)。

\section{末梢迷路に由来するめまい発作}

一一特に迷路の興奮によって起こるめまいと 迷路の麻瘒によって起こるめまいの差異 末梢迷路に由来するめまい発作は健側に比べ て, 患側の迷路が,

(1)興奮状態を呈した時

(2)麻痺状態に陥った時

(3)麻痺状態から急激に賦活した時 
の何れかによって起こる.

しかし「迷路の興奮によって起こるめまい」 と「迷路の麻㽻によって起こるめまい」とでは 些か様相が異なり，例えば，めまい発作時の眼 振を比較してみると，迷路の興奮期は患側に向 かい(刺激性眼振), 麻痺期では健側に向から （麻痺性眼振）ことが知られている。そこで，

（i）耳性めまい発作中に刺激性眼振のみられ た例（irritative case，I 群）24例

(ii ）発作開始後 6 日以内に麻疩性眼振のみら れた例 (early paralytic case, $\mathrm{P}_{1}$ 群) 24 例

（iii）発作開始後 7 日以降に麻㽻性眼振のみら れた例 (late paralytic case, $\mathrm{P}_{2}$ 群) 24例 の各群の ENG および重心動摇図をコンピュー ターにより解析し比較した結果, 次のような差 異が認められた。

1. 迷路の興奮によって起こるめまいの特徵 a) 眼 振

急速相が患側に向い, 頻度も多く且つ速い活 発な眼振であり, 振幅は大小不揃いである.こ の眼振は健側下頭位で増強する傾向にある（石 川ら ${ }^{1)}$.

b ）重心動摇

動摇面積が増大し，且つ方向性は分散してあ たかも回転の勢いを失ったコマの様な動きをす る $($ 太田2)

c）めまいの性状

フラフラ感よりも回転感を訴える例が多い (朴沢ら ${ }^{3)}$ ).

2. 迷路の麻痺によって起こるめまいの特徵 a ）眼 振

急速相が健側に向かい, 刺激性眼振に比べて 振幅が小さい，初期は頻度も多く活発であるが， 患側下頭位で増強し, 健側下頭位で減弱する傾 向にある．発作開始後日時が経つにつれて眼振 の頻度, 振幅, 速度ともに減少し, 眼振間隔の 変動幅も大きくなる(石川ら尚).

b ）重心動摇

動摇面積が増大し, 且つ動摇に方向性があり
眼振の急速相方向へ速く動摇する，身体は丁度 “弥次郎兵衛”の様な左右への動摇をし眼振緩 徐相方向へ倒れ易くなる（太田视）。

c）めまいの性状

特に発作開始より日時が経つにつれて回転感 よりもフラフラ感を訴える例が多くなる（朴沢 $5^{3)}$.

\section{耳性めまい発作の経過 （患側迷路の障害される過程）}

前述の様にめまい発作中, 迷路病態がどの様 に変化するか? は具体的によく知られていない。 これを検索する目的で動物の迷路に実験的に侵 襲を加え, その障害される過程を継時的に観察 する事は可能であるが，めまい症例の診療中， 或る疾病によって迷路が障害される過程を詳細 に観察出来る機会は少ない，しかし，ここに臨 床例でも観察出来る格好の例がある. それは次 に述べるメニエール病に対する超音波照射術中 の眼振変化である.

1. 超音波照射中にみられる迷路の反応

メニエール病の治療として, 患側迷路に超音 波を照射し, その機能を破壊後, 中枢の代償に よって安定した平衡状態を得ようとする手術法 がある。

照射を始めると先ず術側に向から刺激性眼振 が現われるが，これは照射に対する迷路の興奮 を意味するものであり, Arslan ${ }^{4)}$ はこの時期を 興奮期と名づけている．さらに照射を続けると 今度は眼振方向が逆転し, 非術側に向から様に なる、いわゆる Arslan の言ら麻痺期である。 この様に超音波によって迷路が破壊される過程 では麻痺に先立って先ず興奮状態が認められる。

末梢迷路疾患に於いても，患側迷路が侵され る際，丁度，超音波照射術中にみられる過程と 同様，麻疩に先立って興奮期が存在するものと 思われる。

2. 耳性めまい発作中の眼振

臨床的に迷路の麻痺に先立って, 興奮期を区 別できる例として，めまいを伴ら突発性難聴を 挙げる事が出来る. 
a ）めまいを伴ら突発性難聴の眼振

厚生省特定疾患「突発性難聴」研究班のま之 めた診断基準に該当する症例の中, めまいを伴 った33例について眼振の方向を調べた結果, 発 症 3 日以内に検査を行った例では患側に向から 眼振が12例中全例に認められた。 これは患側迷 路の興奮を示す刺激性眼振と思われる.これに 対して発症 6 日以降に検出された眼振は健側に 向からものが21例中18例と圧倒的に多く認めら れ, 麻瘏性眼振が発現したと考えられる（朴沢 $\left.5^{5)}\right)$. 尚, 発症後 6 日以降, 少数例に認めら れた患側向き眼振は何れも治療中, 聴力の回復 し始めた時期に現れたものであり，いわゆる回 復期眼振と考えられる.

この様に, 突発性難聴では屚々迷路の麻痺に 先立って興奮期が認められるという典型的迷路 の障害過程が観察出来るが, これも, 本症が健 康な迷路に突然発症するといら特徵的な罹患過 程に由来するものと思われる。

b ) 前庭神経炎の眼振

本症では突発性難聴と異なる様相を示し, 自 験例および報告例を調べて見ても眼振が患側に 向から例は認められなかった. 即ち, これ迄に 観察出来た眼振は発症 3 日以内のものでも全て 麻瘒性眼振であった。

本症の障害の中心は前庭第 1 次ニューロンで あり, これを裏付けるものとして, 前庭器官に 障害の無かった剖検例も報告されている. 従っ て, 後迷路性障害に由来すると思われる本症で は迷路障害に特有の眼振の二相性变化が認めら れず，臨床的にも迷路の興奮期を捕捉出来ない のでは無いかと推測される.

c ） メニエール病発作期の眼振

メニェール病では前二者と異なり, 発作期の 眼振はさらに複雑である. 文献的にメニェール 病発作期の眼振を調べてみると, 方向が一定で あるが，患側向きょりも健側向きの方が多いと する者 (Arslan, 徳増, 吉田, 渡辺, Altmann, Mathe, Beck), 健側向きょりも患側向きが多 いとする者 (Grahe, Brunner, 橋元, Gunther,
Stenger), 又, 発作中に眼振方向が変化し, 健 側向きから患側向きに变わるとする者（McClure, 吉田, 吉本), 逆に患側向きから健側向 きに変わるとする者（徳増, Meissner) 等, 報 告者によって結果が区々である.

筆者の自験例 55 例についてみても, 方向が一 定で健側に向から者が20例, 患側に向から者が 14例, 方向が変化し患側向きから健側向きに变 わる者が12例, 健側向きから患側向きに変わる 者が 9 例あり, 一定の傾向は認められなかった (朴沢6).

同じ迷路性疾患でありながら, 突発性難聴と 異なり,メニェール病の発作中の眼振がこの様 に多様性を示すのは本疾患特有の発作のメカ二 ズムが関係している為と思われる. そこで, 次 項ではメニェール病発作モデル動物の研究より 得られた「発作中の迷路病態の変化および前庭 神経核の興奮様式」について述べる事とする.

$$
\text { メニエール病めまい発作のメカニズムと }
$$

\section{迷路病態の変化に関する実験的考察}

1. 膜迷路破裂説について

メニェール病の本態が内リンパ水腫であろう と言う考えは, 剖検例や臨床成績（内リンパ整 手術の効果, グリセロール・テストの成績, 蝸 電図所見等), さらに動物を用いた内リンパ水 腫モデル実験の結果より略々間違いないものと 思われる。

本症の特徵である「反復するめまい発作と変 動する聴力」のメカニズムを説明するのに, Schuknecht7) は内リンパ水腫説を前提として 膜迷路破裂説を提唱したが，これは「内リンパ 水腫の亢進によって膜迷路の何処かに破裂が生 じ，そこから高カリウムの内リンパ液が外リン 八腔へ漏出する結果, 前庭終末が刺激されてめ まいが起こる」といら考えである. 反復するめ まい発作と变動する聴力は, 内リンパ系の破裂 と修復とを繰り返す過程に因るという. その後, 剖検例の中から膜迷路破裂部の修復像と思われ る所見が報告され, 又, 高カリウムの人工内耳 液で外リンパ腔を灌流した Silverstein ${ }^{8)}$ の動物 
実験によって，この説の妥当性が裏付けられて いる.

さて，これまでに膜迷路破裂説を前提として 外リンパの高カリウム化と眼振との関係を考察 した論文が種々報告されている．Dohlman ${ }^{9)}$ は 最初, 前庭神経の不完全脱分極が起こって刺激 性眼振が出現するが，さらに脱分極が進むと眼 振方向が変わって麻痺性眼振が現れるという。

これに対して，Molinari10) は最初に現われる刺 激性眼振は前庭感覚細胞の興㗜に因るものであ り, 後に続く麻痺性眼振は中枢神経系の抑制的 反動作用 (inhibitory rebound) であるとしてい る. 又, Meissner ${ }^{11)}$ は外リンパの高カリウム 化が前庭感覚細胞と神経ニューロンとの間のシ ナプスに直接作用して脱分極を起こし，それに よって生ずる前庭ニューロンのインパルスが左 右前庭神経核間のトーヌスの不均衡をもたらし, 眼振が出現するとしている. その際, 外リンパ の高カリウム化が強い時は, シナプスの脱分極 が強く起こって健側前庭神経核優位のトーヌス 不均衡が現われ，その結果として麻痺性眼振が 出現する. 一方, 外リンパの高カリウム化が弱 い時は脱分極も弱く，この場合の前庭ニューロ
ン・インパルスは患側の前庭神経核優位のトー 又ス不均衡をもたらして刺激性眼振が現われる といら. 従って, 眼振がどの方向に向からかは 膜迷路破裂の程度, 即ち, 高カリウム化の進行 程度によると説明している。これらの報告はメ ニエール病発作期の眼振の謎を解く鍵になるも のと思われるが，しかし何れの考えも単なるス ペキュレーションに過ぎず，その実験的根拠か 記載されていない，そこで，次項では外リンバ の高カリウム化によって炭起される眼振, 迷路 病態の変化および左右前庭神経核の興奮性の変 化について，筆者らがこれまで行って来たモル モットの実験結果を報告する。

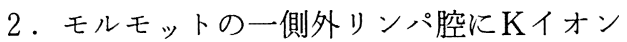
を導入した際に観察される眼振の変化

前述の様に, Silverstein ${ }^{8)}$ は外リンパ腔を人 工内耳液で灌流し，外リンパの高カリウム化を 起こさせたが，筆者らは外リンパ腔灌流を行わ ずに，中耳腔より $\mathrm{K}^{+}$イオンを外リンパ腔に導 入し, 高カリウム化を起こさせる方法を見出し た. 即ち, 正常モルモットの正円空窩に飽和塩 化カリウム液を滴下し，それによって起こる外 リンパ腔の $\mathrm{K}^{+}$イオン濃度変化を観察してみる
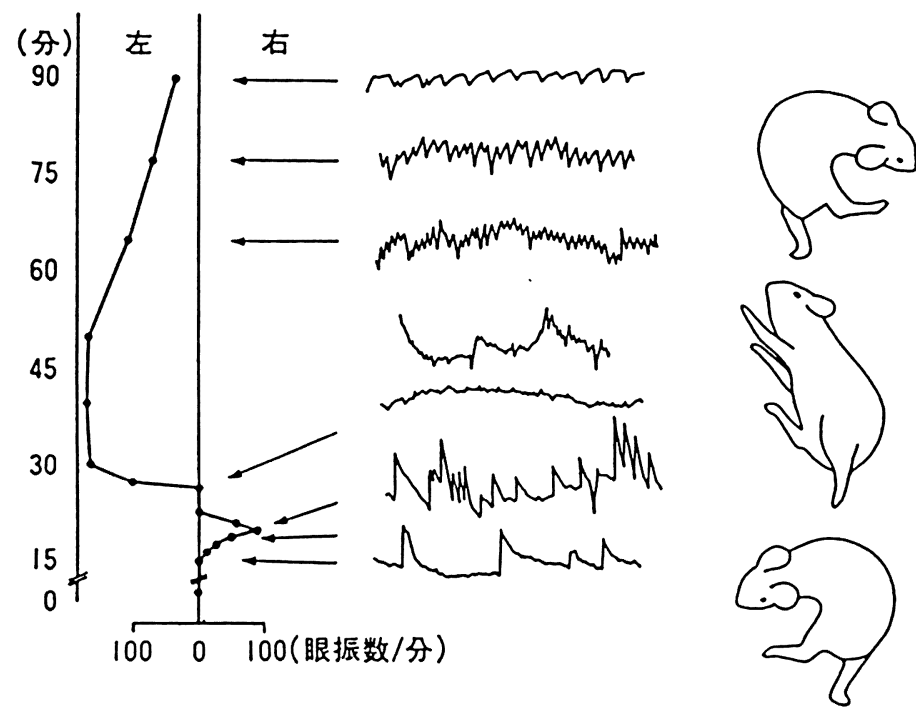

図 $1 \mathrm{~K}$ +導入後のモルモットの反応の経時的変化 
と, 最初外リンパの $\mathrm{K}^{+}$イオン活量が 3.34 土 $1.17 \mathrm{mM} / \mathrm{L}, \quad(\mathrm{n}=21)$ であったのが, 滴下後 1 分前後より上昇し始め，20分後ピーク (178 $\mathrm{mM} / \mathrm{L})$ に達した後, 徐々に下降する事が判明 した.このKイオン濃度の上昇速度は滴下する 塩化カリウムの濃度に左右され，1 mol 溶液を 使用した場合の最高値 $(36 \mathrm{mM} / \mathrm{L})$ は飽和液の 場合に比べて，はるかに低い值を示した。尚 $\mathrm{K}$ イオン活量は蝸牛基底回転の鼓室階に刺入した $\mathrm{K}$ 選択性微小電極により測定した（池野 ${ }^{12)}$ ). 著者らはこのイオン導入効果をさらに確実にす るためにイオントフォレーゼ法を採用して次の 様な実験を行って来た. 即ち, 正常モルモット の右鼓室内に飽和塩化カリウム液 $0.2 \mathrm{ml}$ を経 鼓膜的に注入した後 $500 \mu \mathrm{A} ， 5$ 分間イオント フォレーゼ法を追加した.

この方法でイオントフォレーゼを終了後, 約 15分後にイオン導入耳側に向から刺激性眼振が 約 5 分間観察される. その後, 数分間眼振の不 明瞭な時期があって，今度は非導入側に向から 麻疾性眼振が解発され，それが $6 \sim 12$ 時間持続 する（図 1 ）。眼振消失後のモルモットは全く 正常に戻り，この反応が可逆的な変化である事 が分かる (福岡 $\left.{ }^{13)}\right)$. その後, この様な眼振は イオントフォレーゼ法を併用せずに，中耳腔内 に塩化カリウム液を注入しただけでも認められ る事が分かり, 種々検討した結果, 使用する塩 化カリウムの濃度が薄い程, 刺激性眼振の持続 時間が延長する傾向を認めた（これは Dohlman や Meissner の考えを裏付けている様に思 われる).

筆者らは正常モルモット60匹にこの実験を行 ったが，何れも刺激性眼振が先行し，次いで麻 痺性眼振に移行するといら同じ経過が観察され た。そこで, 前者を刺激性眼振発現期, 後者を 麻疾性眼振発現期と名付け，両期の各々の発現 機序について検討を行った.

3 . 刺激性眼振発現期

a ）体平衡の異常

体は眼振の急速相方向へ偏倚し, 非注入耳側
（左側）へいわゆる“つ”の字型に屈曲する（図 1). 水槽に入れると，モルモットは反時計方 向即ち非注入耳側方向へ円を描いて回旋し乍ら 遊泳し, 直進する事が出来ない。この様相は前 述の刺激性眼振発現中のめまい患者が勢いを失 ったコマの様に重心が動摇するのとよく一致し ている.

b) 迷路病態

この時期のモルモットを断頭し，前庭迷路の 形態学的観察を行ったが, 透過電顕によっても 感覚細胞の形態学的变化は認められなかった (福岡13)).

しかし, 組織化学的に前庭感覚細胞の酵素活 性を調べて見ると, 明らかに六進が見られ, 刺 激性眼振が前庭並びに半規管膨大部稜感覚細胞 の興奮によって発現している事が判明した. 即 ち, Mayahara ${ }^{14)}$ の方法に従って, Na-K-ATPase 活性の変化を検索した結果, Kイオン導入 側の感覚細胞が非導入側に比べて強い活性を示 した.

ATPase 活性は感覚細胞および支持細胞の細 胞膜に認められ, 特に dark cell の領域に強く 認められる酵素であるが ATP が ATPase の作 用により $\mathrm{ADP}$ と $\mathrm{P}$ 水解する際, 発生する高 エネルギーが膜の能動輸送に用いられ, 従って, この活性が高い程感覚細胞の興奮性も六進して いると推測できる.

本実験に於けるモルモットの迷路を電顕的に 観察すると感覚細胞の細胞膜表面と神経盃の間 に存在する ATPase が強く染まっており, 高 カリウム化の影響がシナプスに作用するといら Meissner の考えと一致する結果が得られた (朴沢 ${ }^{15)}$, 朴沢 (孝) $\left.{ }^{16)}\right)$.

c）左右前庭神経核の興奮性

前庭神経核の興奮性はエネルギー代謝に必要 な糖消費量を測定する事によって評価する事が 出来る. 本実験では Sokoloff17)の方法に従い, 前庭神経核の糖消費量を測定した。

即ち, 本測定に用いられる deoxy-D-glucose は glucose と同じ機序によって血液脳関門を通 
り, 脳組織内に取り込まれるが，エネルギー代 謝によって glucose の方は $\mathrm{CO}_{2}$ と $\mathrm{H}_{2} \mathrm{O}$ に分解 されるのに対し, deoxy-D-glucose は分解され ずにそのまま脳組織内に蓄えられるので，この 蓄積量を測定すれば，どの位エネルギー代謝が 行われたかを知る事が出来る.実際は放射性の Deoxy-D-14C-glucose を用いて，その $100 \mathrm{uci} /$ $\mathrm{kg}$ を腹腔内に注射し,一定時間後のエネルギー 代謝によって消費された glucose 量と同じ量の 脳内 RI 蓄積量をオートラジオグラフ法により 測定した.さて, 本実験の刺激性眼振発現期に 於けるモルモットのオートラジオグラフは, 直 接めまいに関係のない小脳半球灰白質の濃度を 100 とした場合にKイオン導入耳側の前庭神経
核の上核の濃度 $(134.0 \pm 2.8, \mathrm{n}=5)$ は反対側の 濃度 $(117.5 \pm 5.0)$ よりも有意に高い值を示し $(\mathrm{p}<0.05)$, 又, 前庭神経核の他の核も同様に $\mathrm{K} イ$ 導入側の方が高い濃度を示すといら結 果が得られた（福士 $\left.{ }^{18)}\right)$. これは反対側に比べ てKイオン導入側の前庭神経核が強く興奮して いる事を示すものである.

川瀬 ${ }^{19 ）}$ は刺激性眼振発現中のモルモットの 前庭神経ニューロンより活動電位を記録した結 果インパルスの著明に増加するのを認めている が，前庭感覚細胞の興奮によってもたらされた インパルスの増加が，この様に同側の前庭神経 核を興奮させ，同側に向から刺激性眼振を若起 したと解棌出来る.
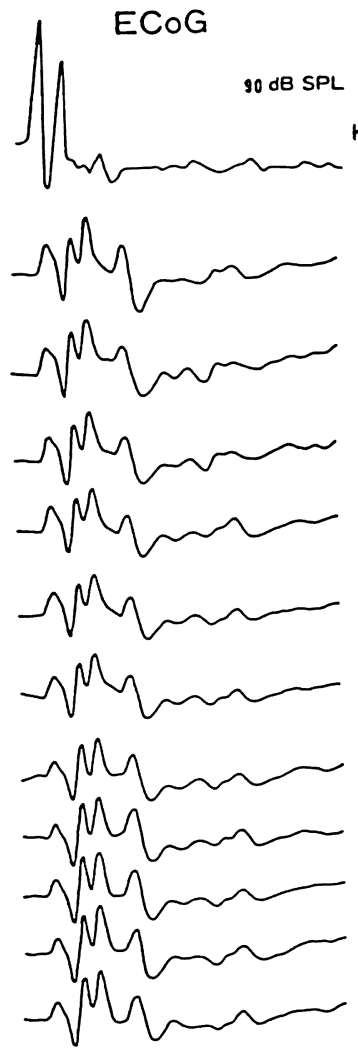

38 分後

41 分嵝

45分後

50 分後

ENG

$\mathrm{KCl}$ 的和液注入前

5 分後

10 分嵝

16 分嵝
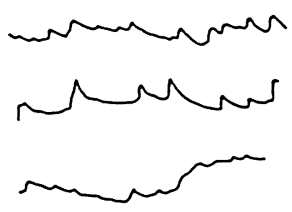

23 分後
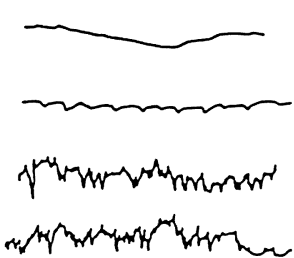

$\mathrm{I} \mu \mathrm{V}$

図 $2 \mathrm{~K}$ - 導入後の $\mathrm{ECoG}$ と ENG の経過 
4. 麻痺性眼振発現期

\section{a ）体平衡の異常}

体は眼振の急速相方向へ偏倚し, 従って刺激 性眼振発現期とは逆にKイオン導入耳側(右側) へいわゆる “く”の字型に屈曲する（図 1 ）. 水槽に入れると，モルモットは体長軸を軸とし てKイオン導入耳側へ向かっていわゆるバーベ キュウ回転をし，遊泳する事が出来ない。この 様相は前述の麻痺性眼振発現中のめまい患者が 弥次郎兵衛の様に重心が左右へ動摇し患側に倒 れ易くなるのとよく一致している.

\section{b ) 迷路病態}

この時期のモルモットを断頭し，前庭迷路の 形態学的観察を行ったが, 刺激性眼振発現期同 様透過電顕によって感覚細胞の形態学的変化は 認められなかった（福岡13)）。この事は本実験 に於ける生理学的变化（眼振, 体平衡障害) が 可逆的なものである事を裏付けている.

しかし，感覚細胞の ATPase 活性の变化に 興味ある所見を認める事が出来た。即ら, 麻㽻 性眼振発現の初期は既に眼振方向が変わってい るにも拘わらず，迷路では，まだKイオン導入 耳側の感覚細胞が反対側よりも強い活性を示し, 興奮性が残存している。しかし，麻痺期が進行 するとその活性が衰え，逆に反対側よりも興奮 性が低下寸る様になる (朴沢) ${ }^{15)}$. この様に眼 振方向の逆転する時期と ATPase 活性の変化 する時期との間に時間的ズレが見られるのは ATPase 活性に限った事ではなく後述のように 他の酵素, 即ちコハク酸脱水素酵素に於いても 同様の時間的ズレが観察された。

c ）左右前庭神経核の興奮性

左右前庭神経核の興奮性の変化は前庭感覚細 胞のそれと異なり, 麻痺性眼振発現期の初期か ら出現した。即ち，この時期に反対側前庭神経 核の糖消費量即ち， RI 濃度 $(136.6 \pm 2.9, \mathrm{n}=5)$ がKイオン導入耳側の前庭神経核濃度 $(110.9$ 土3.8）上りも有意に高く $(\mathrm{p}<0.05)$ ，上り強い 興奮性を示した（福士）即ち，反対側前庭神経 核優位のトーヌス・アンバランスが反対側に向
から麻痺性眼振を引き起こしたものと考えられ る. この事より考えて, 術側迷路の興奮性の変 化は左右前庭神経核にトーヌス・アンバランス を起こす引き金とはなるが，直接，眼振の方向 を決定するのは左右前庭神経核のトーヌス・ア ンバランスであると言える.

5.メニエール病発作期の症状と本実験結果 との関係

a ) 発作期眼振の解釈

筆者らの実験はメニエール病の内リンパ水腫 説に基づいた膜迷路破裂説を前提として行った ものであるが，本実験結果より，メニエール病 のめまい発作中に見られた刺激性眼振は患側迷 路の感覚細胞の興奮が同側前庭神経核優位の緊 張の不均衡を引き起こし, 発現したものである と推測できる. 一方, 麻瘏性眼振は患側迷路感 覚細胞の興奮性の減少が反対側前庭神経核優位 の不均衡を引き起こし，それによって発現した と解釈出来る。また, 膜破裂が大きく, 高カリ ウム化が急速に進行すれば, 刺激性眼振の発現 期が短く, 直ぐ麻痺性眼振が現われる可能性も 本実験結果より説明出来る.

次に，発作中に眼振方向が变わる場合である が, 患側から健側へ変わる場合は度々触れた様 に, 迷路障害は本来, 興奮から麻㽻に移行する いわゆる二相性経過をたどるものであり，その 機序は本実験より説明出来た様に思う。しかし， めまい発作中に健側より患側に変わる眼振の機 序は本実験より説明する事が出来なかった．本 実験では中耳腔に注入する $\mathrm{KCl}$ の濃度を種々 変えたり, 或いは, $\mathrm{K}^{+}$イオンの導入方法を工 夫しても常に解発される眼振は患側向きから健 側向きに変わる二相性経過をたどり, 反対に健 側向きから患側向きに変わる眼振は認められな かった。

メニエール病の特徴はめまい発作を反復する 事であり, 従って, 健側から患側に変わる様な 眼振は，発作を繰り返す中に迷路病態並びに， それに伴ら中枢の反応が変化することにより出 現する可能性も考えられる. 本実験では迷路に 
形態学的変化が認められず, 従って, 生理学的 变化も可逆的であるので, 繰り返し同じモルモ ットに $\mathrm{K}^{+}$イオンの導入を行えば，或いは健側 向きから患側向きに変わる眼振が認められる可 能性も考えられる. しかし，内耳に可逆的な变 化を起こす事の可能な本実験法も直接, 中耳腔 に $\mathrm{KCl}$ を注入している関係で, 中耳腔の粘膜 はかなり障害が見られ，反復実験が困難な状沉 にある，その為，目下，実験を繰り返す為の対 策を考慮中である.

b ）発作期の難聴の悪化とめまい発現との関 係拉よび夫々の起こり方の差異について メニェール病の難聴ではいわゆる S 型オージ オグラムが多く, 又グリセロールテストで聴力 改善が見られる事や，蝸電図検査で $-\mathrm{Sp}$ の増 大を認める事等は全て内リンパ水腫に基づく Tonndorf ${ }^{20)}$ の理論で説明が可能である. しか し, 発作期に増悪する難聴のメカニズムや聴覚 補充現象陽性の機序は単に, 内リンパ水腫の六 進のみでは説明がつかない。

そこで筆者らは，めまい発作によって増覀す る難聴と前庭機能障害との関係を本実験成績か ら考察してみた。

即ち, モルモットの外リンパ腔にKイオンを 導入後, 蝸電図の変化と眼振の経過とを対比し 乍ら観察すると, 図 2 に示すように, 蝸牛では 眼振の発現する以前に既に電位の低下が始まっ ている事が分かる(福岡) ${ }^{13)}$ 。本実験では正円 空膜を通してKイオンを蝸牛の鼓室階に導入し ている為, 外リンパの高カリウム化は先ず楛室 階に始まり，そこから漸次，前庭階を経て前庭 の外リンパにおよぶと推測される．従って本実 験では蝸牛の方から先に影響が現われたと考え られるが，実際，メニェール病の症例では本実 験と異なり, 発作中に蝸牛之前庭とで，どちら の障害が先行するのか？ 或いは両者が同時に 発現するのか？ 各症例によって異なると思う． しかし，発作によって悪化する難聴のメカニズ ムとめまいの起こり方は本実験の結果を基にし て, 膜迷路破裂説上り説明が可能であると考え
られる。一方, 図 2 が示すよらに, 蝸電図の電 位は最初から低下し，所謂一相性变化を示すの に対し，前庭では度々述べている様に最初興奮 し，それから麻痺に至る二相性変化を示してい る.これは蝸牛と前庭の障害との間に存在する 本質的な差として誠に興味深い所見と思われる。 そこで蝸牛と前庭の感覚細胞のコハク酸脱水 素酵素活性の変化を各ステージ毎に比較検討し てみた。この酵素は TCA サイクルに属し反応 連鎖を円滑に回転させる役を果たしているが， エネルギー代謝が盛んな時はその活性も高くな り, 感覚細胞の興奮性を知る為の指標となる.

筆者らは Nachlas ${ }^{21)}$ の方法に従い，酵素活性 の変化を検討したが，刺激性眼振の発現期では 前庭感覚細胞の酵素活性の亢進が見られるのに 対し，蝸牛の感覚細胞では既に活性の低下が認 められている，麻痺性眼振発現期になると，前 庭では最初まだ興奮が残っているがその後, 酵 素活性が低下して来る。これに対して蝸牛では さらに酵素活性の低下が進行する. 即ち感覚細 胞の興奮性に於いても前庭では二相性, 蝸牛で は一相性の変化を示すといら本質的な差が認め られた。尚, 蝸牛感覚細胞の酵素活性の低下は 内有毛細胞よりも外有毛細胞の方に著明に認め られ，これが聴覚補充現象の機序を説明出来る 所見と思われる（朴沢ら）.

この様な末梢受容期に於ける感覚細胞の態度 は夫々の神経核にも反映し，前述のオートラジ オグラフ法で測定した糖消費量を比較してみる と, 前庭神経核では最初に興奮が認められた後, 低下寸るといら二相性の変化を示したのに対し， 蝸牛神経核では最初から低下するといら一相性

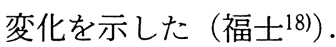

以上の実験結果から考えて，メニエール病の 変動する中低音部の難聴は, 内リンパ水腫を基 盤とする内耳伝音障害（Tonndorf ${ }^{20)}$ の理論） が主体であるが，これに頻回の発作によって感 音性の障害因子が加わって行くものと推測され る.その機序として,膜迷路の破裂による外リン パの高カリウム化が原因していると考えられる. 


$$
\text { まとめ }
$$

1) 耳性めまいの診療に, 迷路病態の変化を 把握する事は適格な治療を行ら上で重要である。 そこで，前庭の興奮によって起こるめまいと麻 痺によって起こるめまいの違いを述べ夫々その 特徵を挙げた。

2 ) 内耳が障害される過程で, 前庭迷路では 先ず興奮が起こり，次いで麻痺に移行するいわ ゆる二相性の変化を示すのに対し, 蝸牛では最 初から低下が始まり，いわゆる一相性の変化を 示すといら, 両者の間に本質的な差異が認めら れた。その過程を実験的に，前庭と蝸牛の感覚 細胞レベルおよび前庭神経核と蝸牛神経核のレ ベルに於いて証明した。

3 ） x ニエール病のめまい発作は「内リンパ 水腫の元進によって膜迷路に破裂が起こり，そ こから外リンパ腔へ露出漏出した内リンパによ り, 外リンパの高カリウム化が起こって前庭終 末が刺激される為に発生する」とするいわゆる 膜迷路破裂説の妥当性を実験的に証明した. 即 ち外リンパの高カリウム化によって，前庭感覚 細胞と神経終末の間のシナプスが刺激されて興 奮が起こり，それによって増大した前庭インパ ルスが同側の前庭神経核の興奮を引き起こし, いわゆる刺激性眼振が発現する.ささらに高カリ ウム化が進むと前庭感覚細胞の興奮が低下し, その影響で健側前庭神経核優位の不均衡が起こ り, 麻痺性眼振が現われる. その一連の過程が 筆者らの実験によって実証された。メニェール 病の発作中, 各症例毎に眼振方向が異なるのは 外リンパの高カリウム化が一律でない事に起因 していると思われる。

4) メニエール病の発作によって難聴の悪化 するメカニズムも膜迷路破裂説で説明出来, 同 時に, 聴覚補充現象の成因も実験によって証明 した.

本論文は第 10 回山陽めまい平衡障害懇談会に於い て講演した内容に最近の筆者の教室の研究成績を加 えて報告した。

\section{文献}

1）石川 馨, 朴沢二郎, 鎌田重輝, 他 : 刺激性眼 振と麻㽻性眼振の差異について, 自発・頭位眼 振の検討. Equilibrium Res $45: 2 ; 91 \sim 100$, 1986.

2）太田修司：一側末梢前庭障害者の重心動摇検査 成績に関する研究, 特に種々の眼振発現期にお ける重心動摇の特徵について. 日耳鼻 $90: 80$ $\sim 89,1987$.

3）朴沢二郎, 石川 馨, 福岡敬二, 他 : 刺激性眼 振之麻㽻性眼振の差異に関する比較研究一 一側前庭機能異常者 80 例の成績一.耳鼻臨床 78 增 $6: 2622 \sim 2628,1985$.

4) Arslan $M$ : Origin of the Nystagmus arising during and after ultrasonic destructive irradiation of the vestibular apparatus. Acta Otolaryng Suppl $192:$ 122 133, 1963.

5）朴沢二郎：めまいを伴う突発性難聴の経過. め まい診療と迷路病態. 43 44頁, 篠原出版, 1985.

6) 朴沢二郎 : メニェール病発作期の眼振の特徵. めまい診療と迷路病態. 45 46頁, 篠原出版, 1985.

7) Schuknecht HF : Meniere's disease; a correlation of symptomatology and pathology. Laryngoscope $73: 651 \sim 665,1963$.

8) Silverstein $\mathrm{H}$ : The effect of perfusing the perilymphatic space with artificial endolymph. Ann Otol Rhinol Laryngol 79 : 754 753, 1970.

9) Dohlman GF : Mechanism of the Meniere attack. ORL $42: 10 \sim 19,1980$.

10) Molinari GA : Alterations of inner ear mechanism resulting from application of sodium chloride to the round window membrane. Ann Otol Rhinol Laryngol 81 : 315 323, 1972.

11) Meissner $R:$ Behavior of the nystagmus in Meniere's attack. Arch Otorhinolaryngol $223: 173 \sim 177,1981$.

12）池野敬一：塩化カリウム溶液豉室注入後に起こ る蝸牛鼓室階カリウムイオン濃度の経時的变化 について. 日耳鼻 $93: 1307 \sim 1313,1990$.

13）福岡敬二 : カリウムイオン内耳内導入の迷路組 
織並びに機能に及ぼす影響に関する研究.日耳 鼻 $90:$ 90 99, 1987.

14) Mayahara $H$ : A New one-step method for the cytochemical localization of ouabainsensitive potassium dependent p-nitrophenyl phophate activity. Histochemistry $67: 125 \sim 138,1980$.

15) Hozawa $\mathrm{J}$ : Experimental studies on mechanism of the Meniere's attack; investigation into vestibulocochlear response of the guinea pigs induced by potassium ion. Auris Nasus Larynx (Tokyo) 13 Suppl $11: 21 \sim 27,1986$.

16) Hozawa $K$ : Effect of high perilymphatic potassium concentration on the guinea pigs vestibular sensory epithelium. Acta Otolaryngol (Stockh) Suppl 435 : 21 26, 1987.

17) Sokoloff $L$ : The $[C]$ deoxy-glucose method for the measurement of local cerebral glucose utilization; theory, procedure and normal value in the conscious and anesthetized albino rat. J Neurochem 28 : 897 916, 1977.

18）福士栄治：外リンパの高カリウム化によって惹
起されるモルモット前庭神経核及び聴覚中枢路 における糖消費量の変化について;オートラジ オグラフィーを用いた研究. 日耳鼻 $94 ， 915 〜$ 923, 1991.

19）川瀬哲明：モルモット自発眼振モデル（K内耳 導入）に批的上前庭神経一次 発放電の経時的観察. 耳鼻臨床 補 $8: 73 \sim 79$, 1986.

20) Tonndorf $\mathrm{J}$ : Vestibular signs and symptoms in Meniere's disorder; mechanical considerartions. Acta Otolaryng (Stockh) $95: 421 \sim 430$, 1983.

21) Nachlas MM : Cytochemical demonstration of succinic dehydrogenese by the use of a new pnitrophenyl substituted ditetrasole. J Histochem Cytochem $5:$ 420 436, 1957.

$$
\left(\begin{array}{l}
\text { 別刷請求先 : 朴沢二郎 } \\
\mathbf{T} 036 \text { 弘前市本町 } 53 \\
\text { 弘前大学医学部耳鼻咽喉科学教室 }
\end{array}\right)
$$

